\title{
Penilaian Kinerja Investasi TI Menggunakan Val IT 2.0 pada Aplikasi Kependudukan Online Pemerintah Kota X
}

\author{
Moch. Aldoris Williandy, M. Imamuddin Adani, Renny Sari Dewi \\ Prodi Sistem Informasi, Fakultas Teknologi dan Informasi, Universitas Internasional Semen Indonesia, Jawa Timur, Indonesia \\ Email: ${ }^{1}$ moch.williandy16@ student.uisi.ac.id, ${ }^{2}$ mohammad.adani@student.uisi.ac.id, ${ }^{3}$ renny.dewi@uisi.ac.id
}

Submitted 01-01-2020; Accepted 10-01-2020; Published 15-02-2020

\begin{abstract}
Abstrak
Penggunaan teknologi informasi (TI) saat ini telah mengalami perubahan yang sangat besar, dari sekadar alat bantu untuk berinteraksi, sekarang beralih menjadi garis depan dalam pelayanan masyarakat khususnya di Lembaga Pemerintahan. Semakin maraknya isu Smart City mendorong setiap kota yang ada di Indonesia untuk terus berinovasi dalam mengambangkan teknologi informasi. Val IT Framework memberikan pedoman, proses-proses dan dukungan praktis yang dapat membantu pimpinan lembaga pemerintahan dalam memahami dan melaksanakan perannya sebagai penentu pengembangan aplikasi TI. Val IT terdiri atas 3(tiga) domain proses utama yaitu Value Governance, Portfolio Management dan Investment Management. Penelitian ini diharapkan dapat menilai pengembangan aplikasi teknologi informasi yang dilakukan di Lembaga Pemerintahan Kota X sebagai tempat studi kasus, sehingga manajemen lembaga dapat menentukan keputusan terbaik dalam pengembangan teknologi informasinya.
\end{abstract}

Kata Kunci: Val-IT, Penilaian, Kinerja, Kependudukan, Aplikasi

Abstract

The use of information technology (IT) now has experienced a very big change, from merely a tool to interact, now turning to the forefront in community service, especially in Government Institutions. Increasingly the issue of Smart City is encouraging every city in Indonesia to continue to innovate in developing information technology. The Val IT Framework provides guidelines, processes and practical support that can help leaders of government agencies understand and carry out their role as determinants of IT application development. Val IT consists of 3 (three) main process domains, namely Value Governance, Portfolio Management and Investment Management. This research is expected to be able to assess the development of information technology applications carried out at City Government Institution X as a case study place, so that the institution's management can determine the best decisions in developing its information technology.

Keywords: Val-IT, Assessment, Application Performance, Population, Application

\section{PENDAHULUAN}

Pentingnya dukungan teknologi informasi (TI)[1] bagi penilaian kinerja aplikasi[2] pada suatu badan pemerintah yang mengurusi kependudukan catatan sipil. Dalam menerapkan TI badan pemerintah membutuhkan perencanaan investasi TI[3] agar TI yang diterapkan dapat dapat memberi manfaat yang maksimal. Untuk itu, badan pemerintahan melakukan penerapan dengan menggunakan aplikasi TI yang dapat membantu kinerja[4] badan pemerintahan. Maka dari itu badan pemerintahan ini menerapkan aplikasi Kependudukan Online yang bertujuan untuk memberikan pelayanan terbaik secara cepat dan tepat . tetapi dalam penerapan investasi TI pada aplikasi Kependudukan Online Badan pemerintahan masih belum merasakan manfaat sesuai dengan yang di harapkan. Hal ini dikarenakan masih terdapat beberapa proses operasional[5] dan penggunaan perangkat pendukung operasional yang belum efisien dimana masih perlu untuk diminimalisasi ataupun dihilangkan dalam segi biaya, risiko, dan penggunaan teknologi informasinya sehingga dapat mengurangi pengeluaran biaya untuk TI badan pemerintahan. Badan pemerintahan ingin mengetahui apakah perencanaan investasi TI aplikasi Kependudukan Online yang dilakukan sebelumnya sudah memberikan manfaat yang maksimal atau belum dan badan pemerintahan ingin mengetahui secara tepat mana manfaat yang terukur dan tidak terukur. Maka dari itu perlu untuk mengukur perencanaan investasi TI untuk melihat manfaat terukur dan tidak terukur, membutuhkan gambaran secara jelas yang berkaitan dengan biaya, risiko, dan manfaat dalamperencanaan investasi TI aplikasi Kependudukan Online Untuk menyelesaikan masalah tersebut, badan pemerintahan kependudukan catatan sipil membutuhkan sebuah framework[6] yang dapat memberikan gambaran mengenai langkah-langkah proses perencanaan investasi TI yaitu Val IT[7] Framework 2.0

\section{METODE PENELITIAN}

Terdapat beberapa tahapan-tahapan penelitian yang digunakan, yaitu :

\subsection{Perumusan Masalah}

Tahap perumusan masalah ini dilakukan untuk menentukan pertanyaan penilaian kinerja yang akan menghasilkan arah bagi tujuan dan manfaat penilaian kinerja.

\subsection{Studi Pustaka}

Tahapan studi pustaka ini bertujuan untuk mandapatkan landasan teori mengenai masalah yang akan dilakukan penilaian.

\subsection{Analisis Penelitian}


Tahapan ini dilakukan analisa dan identifikasi yang berfungsi untuk mengetahui apakah penerapan aplikasi kependudukan online sudah memberikan manfaat sesuai dengan yang tujuan lembaga pemerintahan terkait atau belum.

\subsection{Tahap Usulan Penelitian}

Tahap usulan penelitian dilakukan untuk memperbaiki proses perencanaan investasi teknologi informasi aplikasi kependudukan online dan mencapai target yang diharapkan.

\section{ANALISA DAN PEMBAHASAN}

Penelitian ini menginvestigasi penggunaan aplikasi kependudukan online menggunakan framework Val-IT yang digunakan pada Dinas Pemerintahan Kota X. Faktor yang diteliti terdiri dari Value Governance, Portfolio Management, dan Investment Management. Value Governance[8] merupakan relalisasi dari penetapan tata kelola, mengontrol, dan memonitor kerangka kerja dari aplikasi Kependudukan Online. Portfolio Management[9] merupakan penilaian terhadap semua portofolio investasi IT selaras dan memberikan konstribusi optimal terhadap sasaran strategis organisasi. Investment Management[10] adalah penjaminan bahwa program investasi TI di organisasi dapat memberikan hasil yang optimal dengan biaya yang masuk akal dan dalam batas resiko yang masih dapat diterima.

\subsection{Value Governance}

Optimasi nilai yang diperoleh atas investasi TI dengan cara :

1. menetapkan tata kelola, mengontrol, dan memonitor kerangka kerja

2. menyediakan arahan strategis bagi investasi

3. mendefinisikan karakteristik portofolio investasi

Hasil didapat dari wawancara langsung dengan stakeholder yang berhubungan langsung dengan tujuan penilaian Value Governance.

Tabel 1. Value Governance

\begin{tabular}{ll}
\hline Domain & Rata-Rata Nilai Temuan \\
\hline VG 1. Memastikan sudah diinformasikan dan dilakukannya forum & 3.4 \\
kepemimpinan & \\
VG 2. Mendefinisikan dan mengimplementasikan proses. & 2.6 \\
VG 3. Mendefinisikan karakteristik portofolio. & 0 \\
VG 4. Keselarasan integrasi manajemen nilai dan manfaat dengan & 1.75 \\
perencanaan keuangan. & \\
VG 5. membangun pengawasan tata kelola yang efektif. & 3 \\
VG 6. Peningkatan praktik menejemen nilai yang terus menerus. & 2 \\
TOTAL & 12.75 \\
Rata - Rata Nilai Domain & 2.125 \\
\hline
\end{tabular}

Pada tabel 1 memiliki justifikasi bahwa Domain Value Governance bernilai 2.125 karena belum ada metode pelaporan yang efektif, belum ada penerapan framework pada sistem kerja, selain itu SOP yang ditetapkan belum berjalan dengan sempurna, sehingga kurang maksimalnya penerapan dalam penggunaan aplikasi Kependudukan Online.

\subsection{Portfolio Management}

Menjamin bahwa semua portofolio investasi TI selaras dan memberikan konstribusi optimal terhadap sasaran strategis organisasi dengan cara :

1. Menetapkan dan mengelola profil sumber daya

2. Mendefinisikan Batasan investasi.

3. Mengevaluasi, prioritasi, dan memilih, menunda, atau menolak investasi baru.

4. Mengelola portofolio secara keseluruhan.

5. Memonitor dan mengevaluasi kinerja portofolio.

Hasil didapat dari wawancara langsung dengan stakeholder yang berhubungan langsung dengan tujuan penilaian Portfolio Management.

Tabel 2. Porfolio Management

\begin{tabular}{ll}
\hline Domain & Rata-Rata Nilai Temuan \\
\hline PM 1. Membangun arahan strategis dan menggabungkan target & 2.67 \\
investasi & 3 \\
PM 2. Menentukan ketersediaan sumber dana. & 2.6 \\
PM 3. Mengelola ketersediaan sumber daya manusia. & 1.6 \\
PM 4. Memilih dan mengevaluasi investasi aplikasi Kependudukan & \\
Online. & \\
\hline
\end{tabular}




\begin{tabular}{ll}
\hline PM 5. Memonitor dan melaporkan kinerja portofolio investasi. & 1 \\
PM 6. Mengoptimalkan kinerja portofolio investasi. & 2 \\
TOTAL & 12.87 \\
Rata - Rata Nilai Domain & 2.14 \\
\hline
\end{tabular}

Pada tabel 2 memiliki justifikasi bahwa Domain Portfolio Management bernilai 2.14 karena belum ada dokumen khusus yang mendasari strategi TI kedepannya, belum memiliki sumber dana yang pasti, dan tidak ada strategi untuk mempertahankan semangat dari SDM bidang IT.

\subsection{Investment Management}

Menjamin bahwa program investasi TI di organisasi dapat memberikan hasil yang optimal dengan biaya yang masuk akal dalam batas resiko yang masih dapat diterima dengan cara :

1. Identifikasi kebutuhan bisnis

2. Membangun pemahaman yang jelas atas kandidat program investasi.

3. Menganalisis alternative

4. Mendefinisikan program dan mendokumentasikan sebuah business case secara rinci.

5. Menetapkan akuntabilitas dan kepemilikan program.

Tabel 3. Investment Management

\begin{tabular}{ll}
\hline Domain & Rata-Rata Nilai Temuan \\
\hline IM 1. Membangun dan mengevaluasi business case investasi TI. & 3 \\
IM 2. Memahami kandidat dan pemilihan investas TI.. & 2.5 \\
IM 3. Membangun perencanaan aplikasi investasi & 4 \\
IM 4. Membangun biaya dan manfaat. & 3 \\
IM 5. Membangun business case investasi TI aplikasi. & 3.33 \\
IM 6. Mengadakan dan mengelola investasi aplikasi TI. & 3.67 \\
IM 7. Memperbaharui portofolio operasional TI. & 3 \\
IM 8. Memperbaharui portofolio business case. & 4 \\
IM 9. Pengawasan dan laporan program & 2.5 \\
IM 10. Penghentian program & 4 \\
TOTAL & 33 \\
Rata - Rata Nilai Domain & 3.3 \\
\hline
\end{tabular}

Pada tabel 3 memiliki justifikasi bahwa Domain Investment Management bernilai 3.3 karena setelah perubahan operasional IT, penerapannya belum maksimal, karena user dan operator masih nyaman menggunakan metode manual. Selain itu masih belum ada catatan pengeluaran biaya khusus untuk pembuatan aplikasi.

\section{IMPLEMENTASI}

Berikut usulan perbaikan untuk setiap domain :

\subsection{Usulan Perbaikan Kematangan Value Governance}

Tabel 4. Usulan perbaikan VG

\begin{tabular}{ll}
\hline Domain & Usulan \\
\hline VG 1 & $\begin{array}{l}\text { Pelaporan dokumentasi, dan sosialisasi harus dilaksanakan secara tepat untuk para } \\
\text { stakeholder yang terlibat } \\
\text { Implementasi Framework dilakukan sesuai dengan tujuan lembaga. Menentukan } \\
\text { prioritas dalam pelaksanaan investasi TI. Dokumentasi harus jelas. }\end{array}$ \\
VG 3 & Portofolio harus segera dibuat untuk panduan pelaksanaan investasi TI. \\
VG 4 & Sebaiknya dilakukan analisis yang tepat untuk mengetahui keberhasilan TI \\
VG 5 & $\begin{array}{l}\text { Laporan investasi TI harus didokumentasikan secara lengkap dan terperinci. } \\
\text { Sebaiknya lembaga melakukan penyesuaian terhadap manfaat secara terus menerus } \\
\text { VG } 6\end{array}$ \\
\hline
\end{tabular}

\subsection{Usulan Perbaikan Kematangan Portfolio Management}

Tabel 5. Usulan Perbaikan PM

\begin{tabular}{ll}
\hline Domain & Usulan \\
\hline PM 1 & Sebaiknya lembaga melakukan analisis hubungan antara alokasi investasi dan \\
& rencana strategis lembaga. \\
PM 2 & Menetapkan prosedur pendanaan investasi TI secara lengkap dan terperinci. \\
PM 3 & Melakukan analisis kebutuhan SDM untuk bagian TI. \\
\hline
\end{tabular}


PM 4 Melakukan evaluasi terhadap business case yang telah diterapkan

PM 5 Melakukan pencatatan dan membuat laporan mengenai portofolio investasi TI

PM 6 Melakukan peninjauan terhadap portofolio investasi TI

\subsection{Usulan Perbaikan Kematangan Investment Management}

Tabel 6. Usulan Perbaikan IM

\begin{tabular}{|c|c|}
\hline Domain & Usulan \\
\hline IM 1 & $\begin{array}{l}\text { Melakukan analisis manfaat dari investasi TI apakah sudah selaras dengan tujuan } \\
\text { dari lembaga. }\end{array}$ \\
\hline IM 2 & $\begin{array}{l}\text { Menganalisis untuk menilai dan mengidentifikasi keselarasan biaya \& resiko } \\
\text { lembaga. }\end{array}$ \\
\hline IM 3 & Membuat business case yang lebih rinci sebagai panduan pelaksanaan investasi TI. \\
\hline IM 4 & Mengukur manfaat dan relevansi investasi penerapan aplikasi. \\
\hline IM 5 & $\begin{array}{l}\text { Membuat business case yang sesuai standar yang telah ditetapkan sehingga selaras } \\
\text { biaya dan resikonya. }\end{array}$ \\
\hline IM 6 & $\begin{array}{l}\text { Melakukan analisis resiko yang akan dihadapi, dan membuat solusi dalam } \\
\text { menangani resikonya. }\end{array}$ \\
\hline IM 7 & Melakukan pembaharuan secara berkala pada portofolio lembaga \\
\hline IM 8 & Menerapkan business case dalam menentukan investasi TI \\
\hline IM 9 & Melakukan pengawasan secara rutin dan terperinci \\
\hline IM 10 & Mempelajari hasil penilaian investasi TI untuk masa depan \\
\hline
\end{tabular}

\section{KESIMPULAN}

Berdasarkan analisis dan identifikasi penilaian kinerja aplikasi TI dalam penelitian ini dapat ditarik kesimpulan bahwa :

Tabel 7. Kesimpulan Nilai

\begin{tabular}{ll}
\hline Domain & Nilai \\
\hline Value Governance & 2.125 \\
Portfolio Managemant & 2.14 \\
Investment Management & 3.3 \\
Rata-rata total & $\mathbf{2 . 5 2}$ \\
\hline
\end{tabular}

Berdasarkan audit tersebut dapat disimpulkan bahwa :

1 Maturity level investasi aplikasi Kependudukan Online Lembaga Pemerintahan Kota X masuk kedalam level 2 (Repeatable) Adanya peningkatan kesadaran akan kebutuhan tata kelola investasi teknologi informasi yang lebih formal. Business case dan laporan status investasi diperlukan untuk sebagian besar investasi, dan terdapat beberapa laporan terbatas mengenai manfaat investasi. Fungsi bisnis dan teknologi informasi bekerja lebih kolaboratif pada kebutuhan pengembalian invetasi teknologi informasi.

2 Dengan adanya langkah-langkah dalam melakukan perencanaan investasi TI aplikasi Kependudukan Online dengan menggunakan Val-IT framework dapat membantu pimpinan mengambil keputusan investasi TI.

\section{REFERENCES}

[1] B. Parthasarathy, "Information Technology," in International Encyclopedia of Human Geography, 2009.

[2] A. Mulyanto, "Sistem Informasi Konsep dan Aplikasi," Yogyakarta: Pustaka Pelajar, 2009.

[3] A. D. W. Soelistyo, L. E. Nugroho, and W. W. Winarno, "Model Analisis Produktivitas Investasi TI Perusahaan," in Seminar Nasional Teknologi Informasi dan Multimedia 2015, 2015.

[4] Moeheriono, Pengukuran Kinerja Berbasis Kompetensi.pdf. 2014.

[5] Parawanto Dwi, "Sistem informasi administrasi dan pendaftaran pasien pada rumah sakit ibu dan anak Sadewa," J. Sist. Inf., 2012.

[6] "Framework," Dev. Sedimentol., 1977.

[7] W. Witanti and Falahah, "VAL IT : Kerangka Kerja Evaluasi Investasi Teknologi Informasi," Semin. Nas. Apl. Teknol. Inf. $2007,2007$.

[8] G. Gereffi, J. Humphrey, and T. Sturgeon, "The governance of global value chains," Rev. Int. Polit. Econ., 2005.

[9] "ANALISIS PERBEDAAN RETURN DAN RISIKO SAHAM PORTOFOLIO OPTIMAL DENGAN BUKAN PORTOFOLIO OPTIMAL," Manag. Anal. J., 2015.

[10] B. A. Wallingford and F. K. Reilly, "Investment Analysis and Portfolio Management.," J. Finance, 1979. 